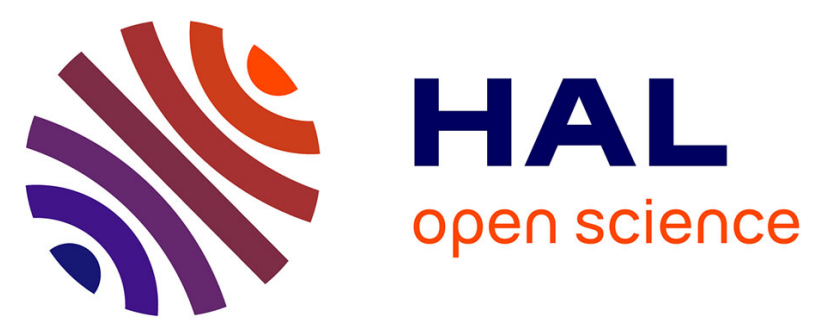

\title{
Thermal Processes for the Valorisation of Waste and Biomass into Energy/Fuel and Useful Materials WasteEng 2008, 3-5 June 2008, Patras (Greece) FOREWORD
}

\author{
Ange Nzihou, Gerasimos Lyberatos, Michel Baron
}

\section{To cite this version:}

Ange Nzihou, Gerasimos Lyberatos, Michel Baron. Thermal Processes for the Valorisation of Waste and Biomass into Energy/Fuel and Useful Materials WasteEng 2008, 3-5 June 2008, Patras (Greece) FOREWORD. High-temperature materials and processes, 2008, 27 (5), p. 291-292. 10.1515/HTMP.2008.27.5.291 . hal-01632792

\section{HAL Id: hal-01632792 \\ https://hal.science/hal-01632792}

Submitted on 31 Oct 2019

HAL is a multi-disciplinary open access archive for the deposit and dissemination of scientific research documents, whether they are published or not. The documents may come from teaching and research institutions in France or abroad, or from public or private research centers.
L'archive ouverte pluridisciplinaire HAL, est destinée au dépôt et à la diffusion de documents scientifiques de niveau recherche, publiés ou non, émanant des établissements d'enseignement et de recherche français ou étrangers, des laboratoires publics ou privés. 


\title{
FOREWORD:
}

\section{Thermal Processes for the Valorisation of Waste and Biomass into Energy/Fuel and Useful Materials}

\author{
WasteEng 2008, 3-5 June 2008, Patras (Greece)
}

\author{
Guest Editors: \\ Prof. Ange Nzihou, Ecole des Mines d'Albi-Carmaux (France), Co-chair of WasteEng08 Conference \\ Prof. Gerasimos Lyberatos, University of Patras (Greece), Co-chair of WasteEng08 Conference \\ Prof. Michel Baron, Ecole des Mines d'Albi-Carmaux (France), Guest Editor
}

\begin{abstract}
The WasteEng Conference Series (http://www.wasteeng.org/) promotes the sustainable Valorisation of Waste and Biomass for the production of energy and useful materials, with emphasis on processes and practices that reduce emissions and life cycle assessment of technologies and end-of-pipe products. The very successful 2008 issue (WasteEng08, Patras Greece) has shown the richness of this ever growing field. This special issue presents a selection of contributions dealing with the utilization of thermal treatment for the production energy/fuel and useful materials. For this purpose, this issue covers a wide variety of cases (waste and biomass streams), processes and approaches.

The management of non food biomass such as chromated copper arsenate treated wood waste is addressed in an interesting way ranging from the valorisation of metal agglomerates such as Arsenic, Chromium, Copper (Kemiha et al) to the production of high carbon content charcoal by relatively low temperature pyrolysis (Mateos) as well as modeling and simulation studies for packed reactor (Govaerts et al.) and particle scale (Rattes et al.). The results presented show a strong research effort in the field.

Similarly, dredged sediments constitute an organomineral waste, since they contain organics and heavy metals. In the paper presented by Ramaroson et al. the calcination aimed at decomposing the organics and engineering final particles with various useful physical properties.
\end{abstract}

A number of contributions deal with carbon materials. The production of Carbon materials is made using various processes. For this purpose, the pyrolysis of biogenic solids (loannidou et al.) and the thermochemical conversion of bean pods by chemical and physical activation researches are developed for the production of carbon materials (Ekinci et al.).

From a more general aspect, using a predictive model, Jung addresses the opportunities of producing gaseous or liquid substitution fuels by pyrolysis or gasification of various industrial waste streams.

An interesting contribution from Escudey et al. dealing with the self-heating of sewage sludge is presented. Complementary data at laboratory and field scale as well as numerical simulations are presented to investigate the self-heating conditions.

The management of radioactive hazardous materials such as nuclear waste is to be addressed in a particular way. Lemont et al. proposed a study on incinerationvitrification with main concerns the volume reduction, the immobilization of radionuclides or heavy metals and the treatment of emissions.

The emission issue is well addressed in the research proposed by Falcoz et al. dealing with the monitoring of heavy metals during waste combustion. There is a strong ongoing effort in the research community on the measurement and on-line monitoring of pollutant that this contribution is a part of. In the same way Fraysse et al. have proposed a full scale technology for enhancing Nitrogen oxides abatement using a selective noncalalytic reduction technique with very significant efficiency. 
In summary, this special issue has assembled papers addressing the valorization of various waste and biomass using various technologies. It can be noticed that the researches proposed cover the whole scale from laboratory to full scale with an emphasis on emission reduction. Modeling and simulation approaches are also presented. This makes this issue of the WasteEng08 Conference on thermal processes for the valorization of
Waste and Biomass into energy and useful materials a very interesting contribution.

\section{Guest Editors:}

Prof. Ange Nzihou, Ecole des Mines d'Albi-Carmaux (France), Co-chair of WasteEng08 Conference

Prof. Gerasimos Lyberatos, University of Patras (Greece), Co-chair of WasteEng08 Conference

Prof. Michel Baron, Ecole des Mines d'Albi-Carmaux (France), Guest Editor 